had to get an additional powerful light and a reading lens to learn what many illustrations were meant to illustrate. For anyone who wants to understand something about the ocean, artistic appeal has been attained at too high a price.

Legends all too often are casual, as on p. 227, where the slate cliffs of Cornwall are depicted below and not above as stated. On p. 100 whiting are said to be mackerel. On p. 243 the Dutch Isle of Schokland is shown before and after reclamation of the surrounding sea, but printing one of the photographs upside down spoils the point. Little thought has been given to the amount of reduction which lettering will stand, as on the chart on p. 182 which has been absurdly reduced.

It is much to be regretted that such evidently high artistic aims by the publishers applied to such an excellent script should have given cause for so much criticism. A better sub-title would have been: 'An Atlas-History of the Conflict of Science and Art', or maybe: 'Two Ways of Looking at Truth'.

L. H. N. COOPER

\section{NEW OUTLOOKS IN OCEANOGRAPHY}

\section{Oceanography for Geographers}

By Dr. Cuchlaine A. M. King. Pp. xii + 337. (London : Edward Arnold (Publishers), Ltd., 1962.) 40s. net.

An Introduction to Physical Oceanography

By Prof. William S. von Arx. Pp. $x+422$. (Reading, Mass. and London: Addison-Wesley Publishing Company, Inc., 1962.) $113 s$.

Equatorial Waters and Currents at $150^{\circ} \mathrm{W}$. in JulyAugust 1952.

By R. B. Montgomery and E. D. Stroup. (The Johns Hopkins Oceanographic Studies, No. 1.) Pp. 68. (Baltimore, Md.: The Johns Hopkins Press; London: Oxford University Press, 1962.) $40 s$. net.

$\mathrm{T}$ HE first two of these volumes are text-books while the third is the first of a new series of research monographs. Oceanography is, by its nature, linked with a number of other scientific disciplines and it is important that its methods and achievements should be presented to students in related fields in a way which will readily attract their attention. Dr. King, in her book, has set out to describe recent discoveries and ideas in oceanography against their basic background in a form which will appeal to geographers. The author surveys almost all aspects of marine science: the form and structure of the ocean basins, the ocean floor, the water masses and their movements and life in the sea. Starting from the beginning, the author has nevertheless brought her account remarkably up to date in many ways: recent ideas on the forma. tion of ocean bottom features, new theories of wavegeneration by wind, observations of deep currents by new techniques and theories of the general oceanic circulation have all been included. In such an ambitious undertaking it is not surprising to find a few errors here and there, while the section on "Causes and Character of the Ocean Currents" contains a number of misleading or ambiguous statements. These are minor blemishes, however, in a valuable book which should appeal to all readers who wish to have a primarily descriptive account of the present state of oceanography.

Prof. Von Arx has treated the subject from the point of view of the physicist approaching oceanographic problems. In a very useful chapter he explains concisely all the essential ideas of fluid mechanies needed to represent motion on the rotating Earth. These are then applied to a treatment of the atmosphere and oceans as a single system before going on to further details of the oceanic circulation. There are chapters on tides and other waves, methods of current measurement and laboratory models. The final chapter, on "The Gulf Stream Problem", reflects the use of this much-explored current system as a means of studying many features of more general application. This is a most stimulating book from the physical point of view and should appeal to geophysicists of all interests, as well as to students of oceanography. There are many excellent illustrations in the book, which is very well produced, but the high price may act as a deterrent to its wide use as a text-book.

In August 1952 an expedition to the equatorial Pacific, under the leadership of Townsend Cromwell, made the first direct observations of the Equatorial Undercurrent, which flows eastwards along the equator below the westward flowing South Equatorial Current. This important, but previously unsuspected, oceanic feature has been named the Cromwell Current after its discoverer, who died in 1958. The preliminary report of this current, published in 1954, naturally aroused great interest and more detailed surveys were made by several expeditions during the International Geophysical Year. A full account of the original work in the R.S. Hugh M. Smith in 1952 has been completed by R. B. Montgomery and E. D. Stroup, who were Cromwell's colleagues on this cruise, and is published as the first of a new series of monographs from the Johns Hopkins Press. This cruise was remarkable for the simplicity of the apparatus and the meticulous care with which the operations were planned and carried out. Apart from the particular interest of its subject, this monograph is a model exposition of how an oceanographic cruise is planned, executed and its results presented. In this respect it provides a fitting complement to the broad perspectives and basic principles expounded in the first two books reviewed.

K. F. BOWDFN

\section{TAR AND BITUMEN IN ROAD CONSTRUCTION}

\section{Bituminous Materials in Road Construction}

(Department of Scientific and Industrial Research: Road Research Laboratory), Pp. xxiv $+611+25$ plates. (London: H.M. Stationery Office, 1962.) 42s.

FOR the first time a text-book on bituminous materials for road construction is available in Great Britainthe word 'bituminous' of course covering both tar and bitumen. The 'black-top' road industry has felt the need for a book of this nature for years, and has long envied other forms of road construction which have had a profusion of literature to support them.

Possibly it is for this reason that many engineers responsible for the design of major road schemes are so well informed about the rigid form of construction-concreteand in many cases so lacking in information about flexible, or black, roads.

This book is the work of members of staff of the Road Research Laboratory, who are to be congratulated on producing such a very comprehensive text-book. This is indeed the purpose of the volume, rather than to provide a practical hand-book for road-makers. It requires supplementation by specifications and other literaturo to fulfil this latter purpose. In the role of text-book it is extremely detailed and covers all aspects of flexible road construction with tar- and bitumen-bound mixtures, ranging from the origin, chemical and physical characteristics of the materials to the detailed design and methods of building roads.

Obviously a work of this nature has takon several years to produce, and it is a little unfortunate that this is reflected in the dates of some of the illustrations, and by the fact that occasionally references are out of date. Also, the text includes several methods of carrying out certain tasks which have now been superseded, for example, the first two methods of applying wetting agents to surface dressing described on pp. 323-328 are now 